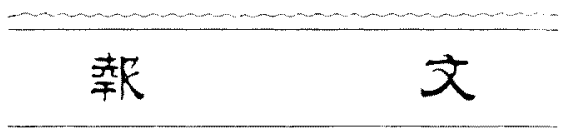

\title{
ヘキザメチレンテトラミンの鑑識と 定量分析とに就て
}

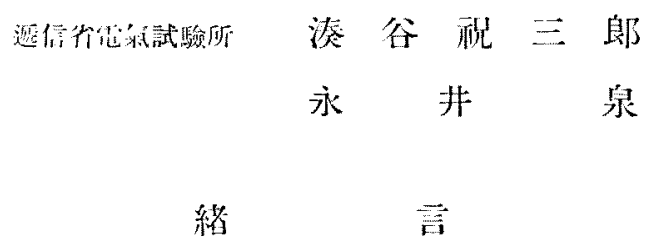

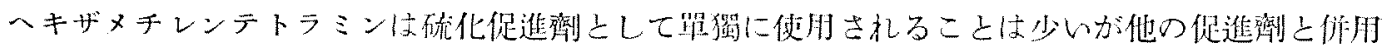

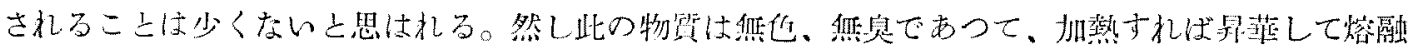

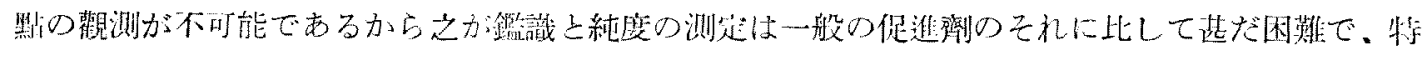

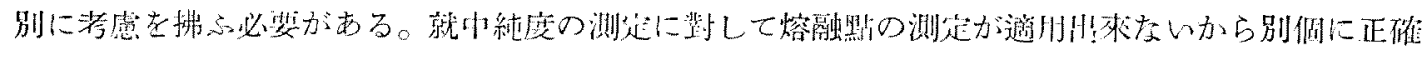

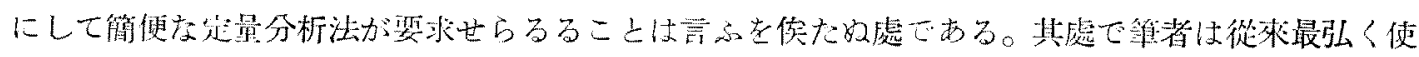

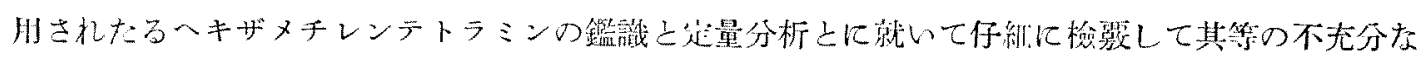

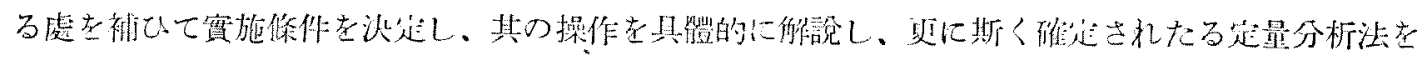

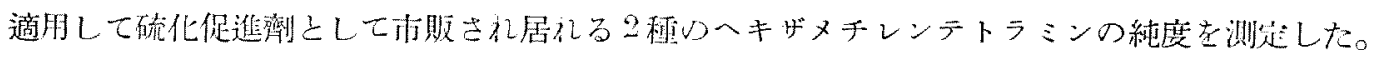

鑑儎法

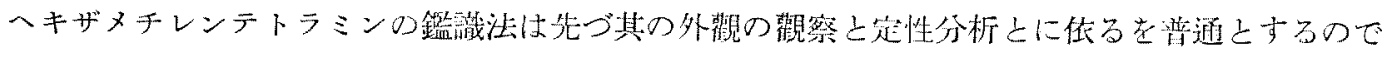

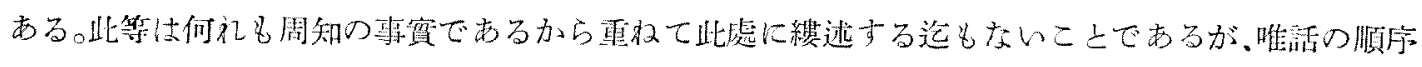

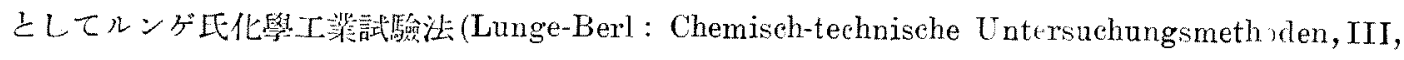

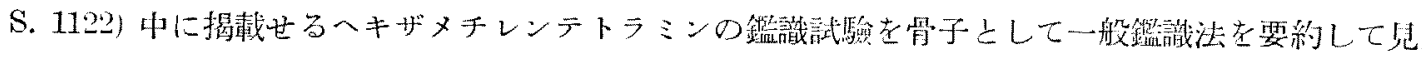
たいと思ふ。

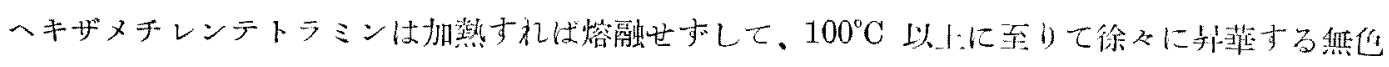

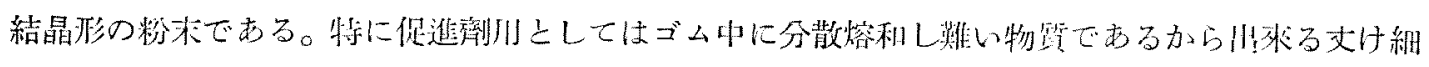

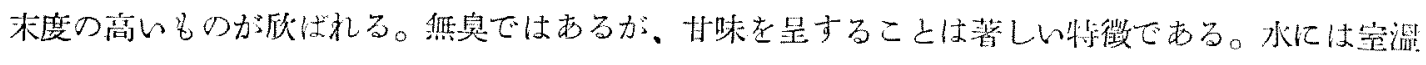

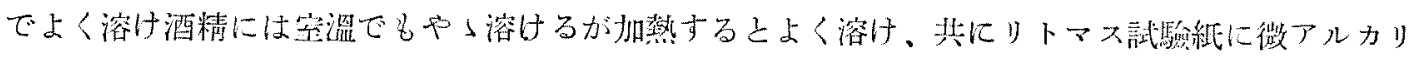

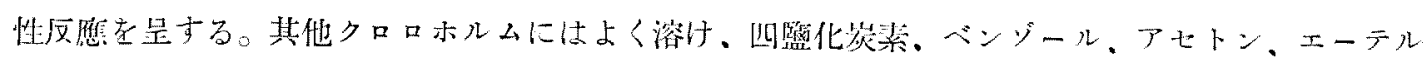


及トルェンには稍与溶竹し、石油ベンジンには全然不溶解である。

本物筫の水溶液 $(1 ： 20)$ を稀硫酸と其に加熱するとフォルムアルデハイトによる刺战息が墢散す

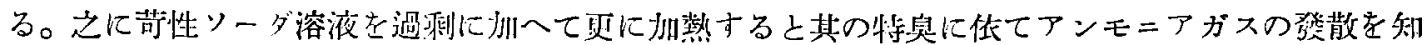
る。

本物筫はメフクシン恶硫酸に對してフォォムアルデハイドの如く 僬紅凹の是仙反應を示すが、此はへキザメチレンテトラミンが分俳

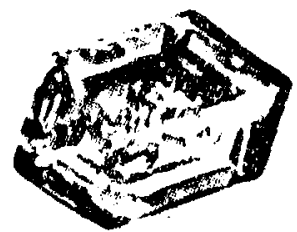

して生成さ礼たフォルムアルデハイドに位て惹起される\&のであつ

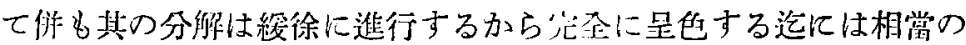
時間圶要する。

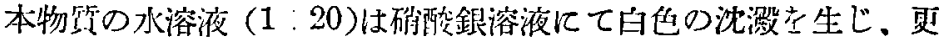

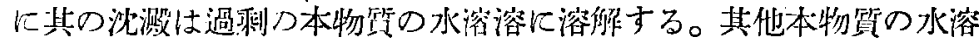

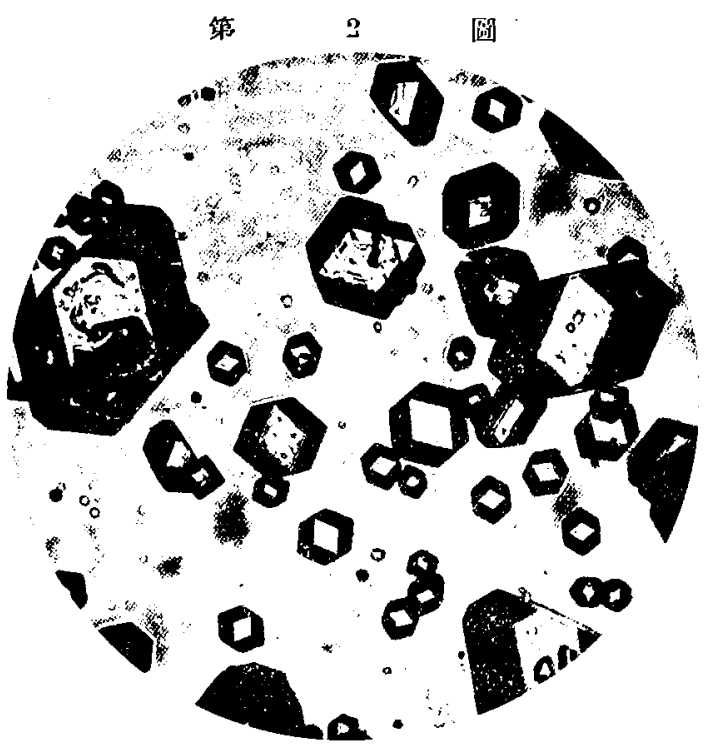
液は昇永乃至は單仁酸の水溶液にて白凹沈澱 を生じる。

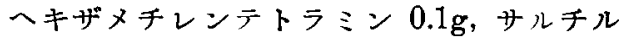
酸 $0.1 \mathrm{~g}$, 濃硫酸 5 ec の混和物を注意しつつ 溫めるとカーミン縕色が發現する特色ある呈 色反應は特に注目す可き集鿰がする。 普通の場合には前記のへキザメチレンテト ラミンの一般鑑䇅法だけで充分と思はれる が、類似の有機物が混在せる場合は之を識别 することは些抗困醮である。斯かる場合には 通に本物筫の檢鏡試驗を施行されれば正分が ないと思はれる。へキザメチレンテトラミン は、科方晶形。12 面䯤の規則正しく而当結晶析州の容易な結晶であつて、(Dickinson and Raymond : J. Am. Chem.Soc., 1923, 45, 22) 酒精より結晶させたものは第 1 圖の如き結晶形を示し、

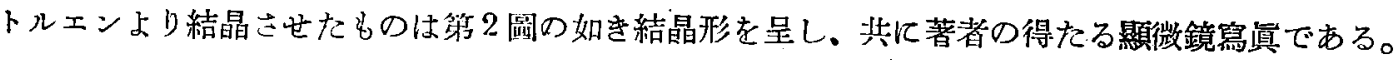

\section{アンモニアの定㽞に依る定量分析法と其成績}

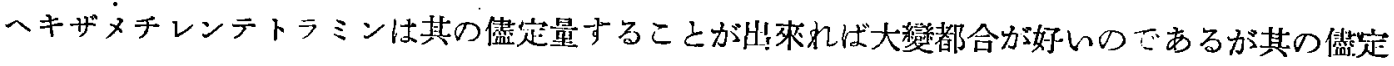

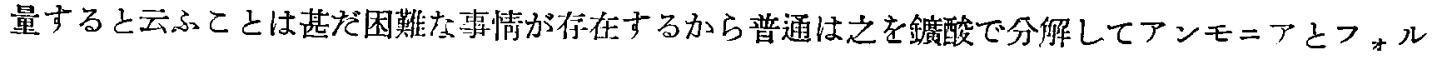
ムアルデハイドとし其中何れか在定量し、その值から元物資の百分率を算出するのが例である。就 中アンモニアを望量することに伭る定量分析法の方が操作簡便で誤管も少いから、一般には此のア 


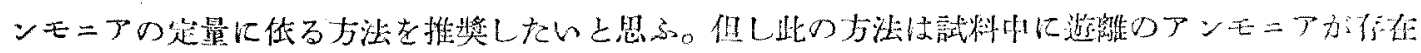

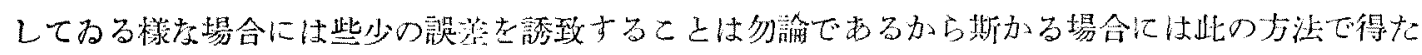

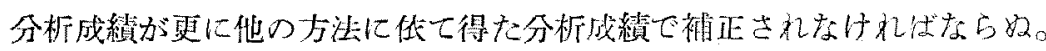

此の定量分析汪に就いてはD. Base 民 (Pharmazeutische Ztg., 1907, 52.851；D-Amer：Apoth.-

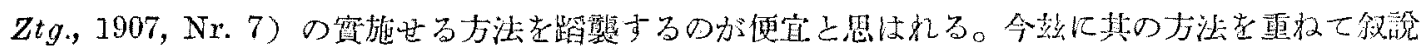

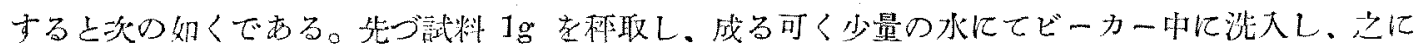

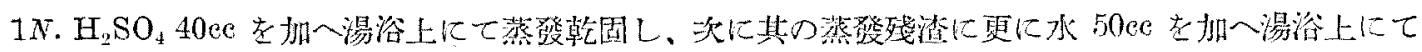

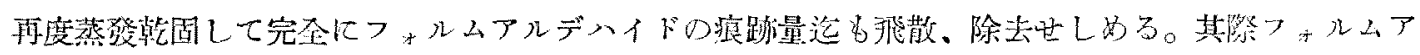
ルデハイドの存否は其の刺载性する特息にて感知することが出來る。叉其際の反應は次の化學方程 式にて亦されるのである。

$$
\begin{aligned}
& \left(\mathrm{CH}_{2}\right)_{6} \mathrm{~N}_{4}+6 \mathrm{H}_{2} \mathrm{O}+2 \mathrm{H}_{2} \mathrm{SO}_{4}=6 \mathrm{HCOH}+2\left(\mathrm{NH}_{4}\right)_{2} \mathrm{SO}_{4}
\end{aligned}
$$

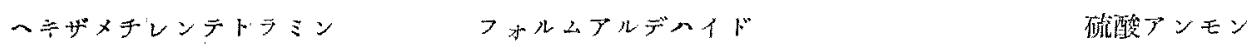

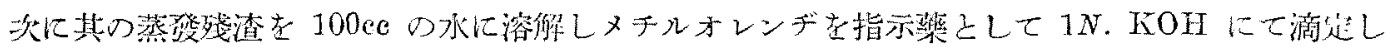

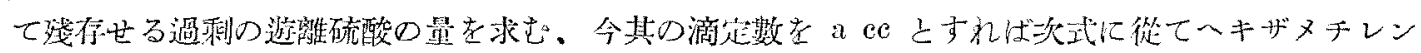
テトラミンの純度が算出される。

$$
(40-a) \times 0.035 \times 100=\text { ーギ゙ホレンラトラミンの純度（\%) }
$$

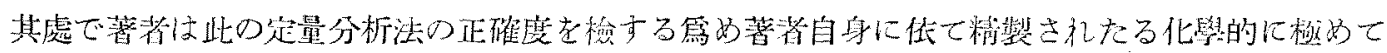

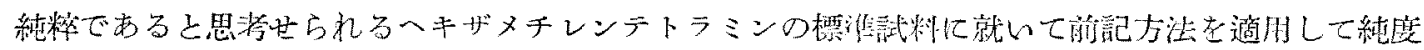

\begin{tabular}{|c|c|c|c|c|}
\hline & & 1 & & \\
\hline \multicolumn{5}{|c|}{ 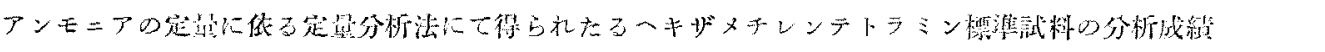 } \\
\hline 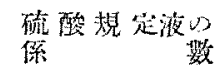 & 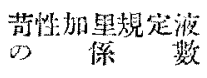 & 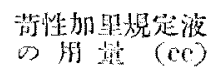 & $\begin{array}{c}\text { 標源試料D暕度 } \\
(\%)\end{array}$ & $\begin{array}{c}\text { 純度の吅均值 } \\
(\%)\end{array}$ \\
\hline 1.012 & 0.9484 & 12.56 & 100.08 & \\
\hline 1.012 & 0.9484 & 12.61 & 99.91 & 99.96 \\
\hline 1.012 & 0.9484 & 12.61 & 99.91 & \\
\hline
\end{tabular}

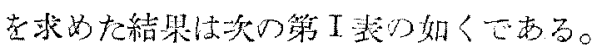

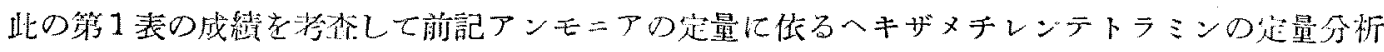

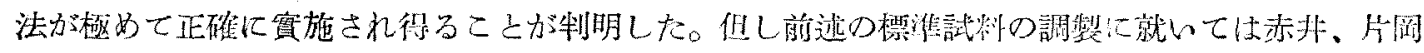

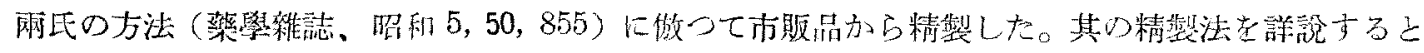

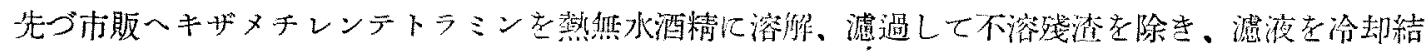

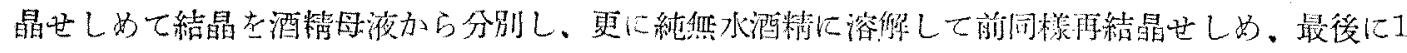

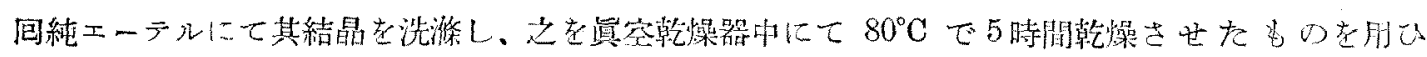
to

更に前記の如く著者自身に依て其の正磼度を㮝せられたアンモニアの定量に依るへキザメチレン 
テトラミン等量分析法を雨ひて 2 稞の市販硫化促進劑用へキザメチレンテトラミンの純度を汌定し

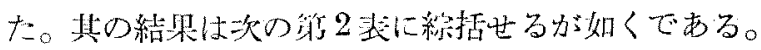

第 2 表

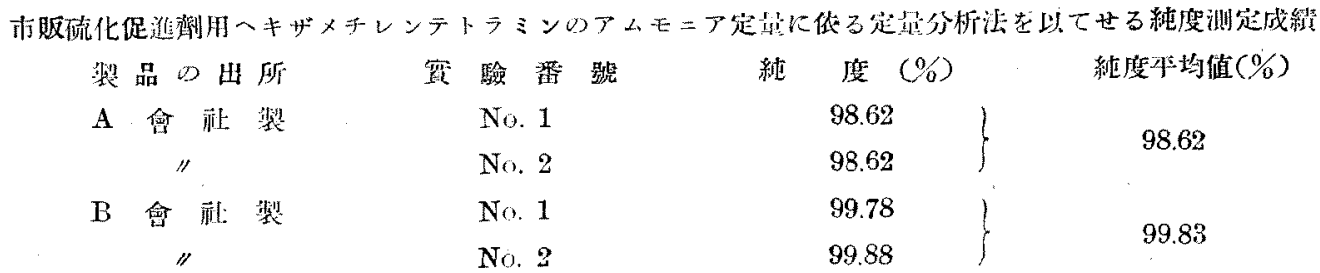

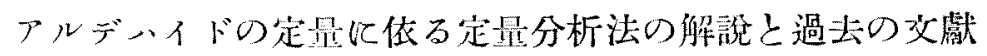

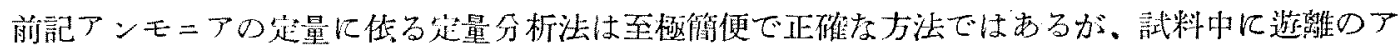

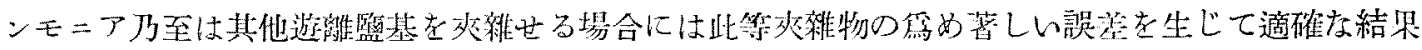
が得られ好から斯かる場合にはアルデハイドの定量に依る定量分析法老適用しなけ机ばなら妨。乍 然パラフォルムアルデハイドの如き遊離のアルデハイドを爽㒕せるが如き場合にはアルデハイドの

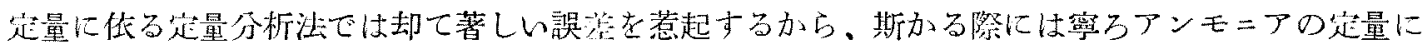
位る定量分析法考推奨しなければなら数。要するにへキザメチレンテトラミンの定量分析に都して は完全なる䦽接定量法が梦いから、アンモニアの定量とアルデハイドの定量とに低る2つの間接定

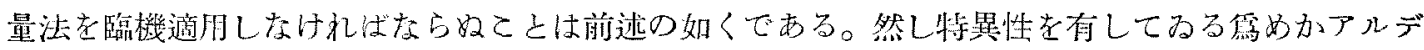
ハイドの定量に依る定量分析啮の方が重肘されてわる樣に思はれる。

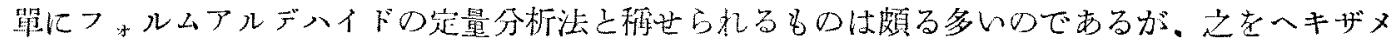

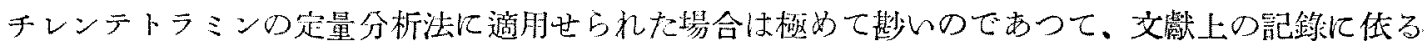

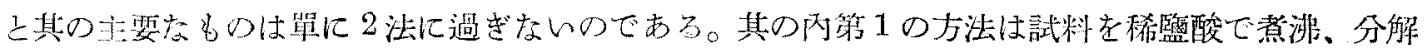
されて、フォルムアルデハイドを遊雖せしめ。此の生成せるフォルムアルデハイドに依りて過剩

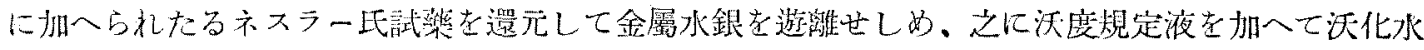

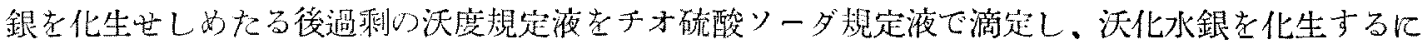
要した沃度量を求めてへキザメチレンテトラミンの含倠量を算出する方法（W. Stüwe：Archiv. d. Parmazie，1914，252，430)て第 2 の方法は試料の溶液老蒸溜、分解し、其際分解されれ遊離のフ ォルムアルデハイドを舍有せる溜出分に就いてフロログルシノール (phloroglueinol)の紅芭化せし

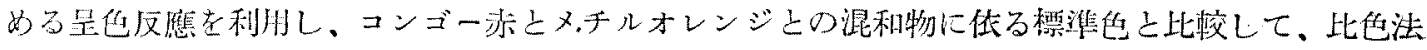

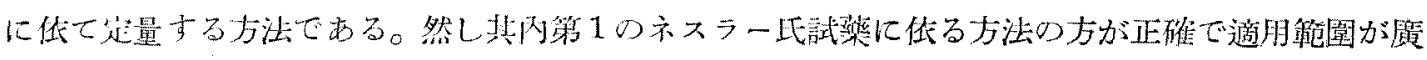
く、一般に推獎されてるると思はれる故此處では此の第 1 の力法のみに就いて将究して見たい思 so 
此處で改めて前記第 1 の方法走詳說すると先づへキザヌチレンテトラミンの試料 $0.5 \mathrm{~g}$ 告利取し

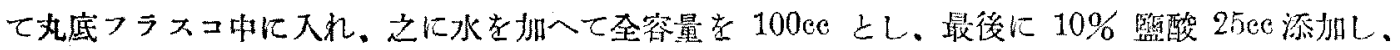

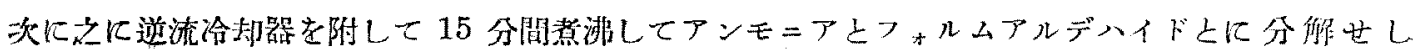
め、續いて之を冷却後冷却管者少量の水にて洗ひ落し、此の洗液と其に炕底フラスコの內容物を 250ec のメスフラスコ中に移して、目盛り迄水を以て立语する。斯くして造られたる溶液 10ce（科 取試料が此の中に $0.02 \mathrm{~g}$ 去舍む筈）をピペットにて探取し、之に本分析の第め特别に考案されれる

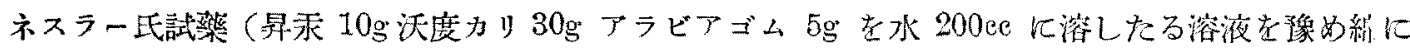

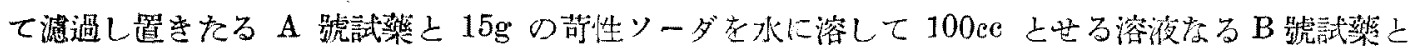

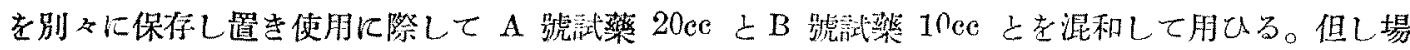

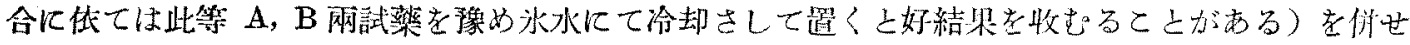

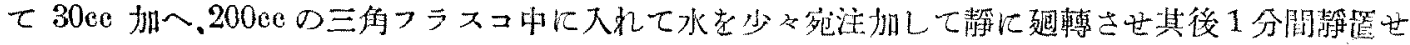

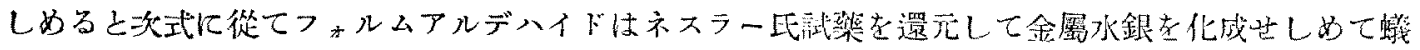
酸に酸化される。

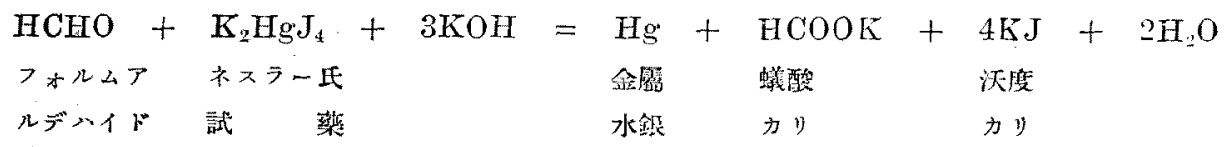

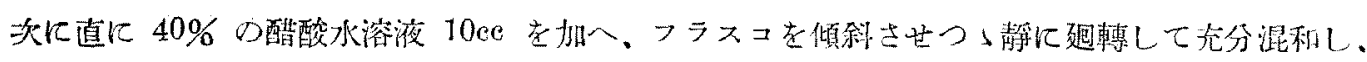
直にビェーレットから $N / 10$ 沃度液 $20 \mathrm{ce}$ 在注加して生成せる金虽水銀索全部沃化水銀に綗成せし

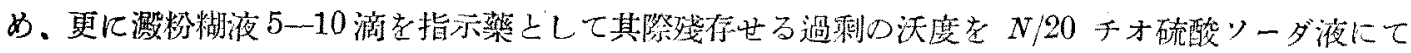
滴定する。然るに $N / 10$ 沃度液 100 はへキザヌチレンテトラミンの $0.001167 \mathrm{~g}$ に該简すると示る

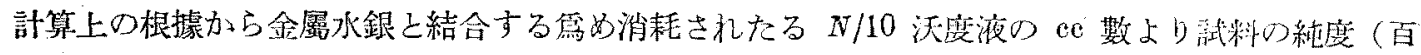
分柰）算出することが出柬る。

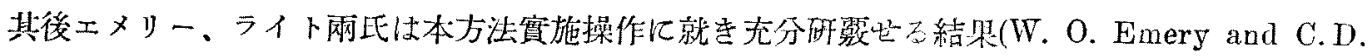
Wright：J.Ind. Eng.Chem., 1918，10，606) 同方法に使肘する 40\% 醋酸溶液添加後 N/10 沃

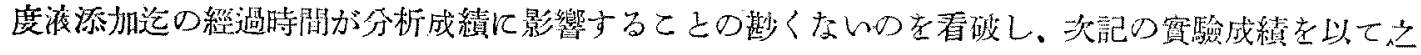
を觹證してるる。

$$
\text { 第 } 3 \text { 裴 }
$$

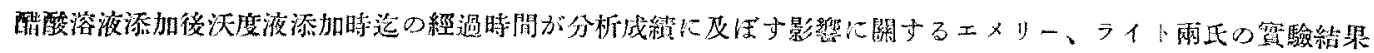

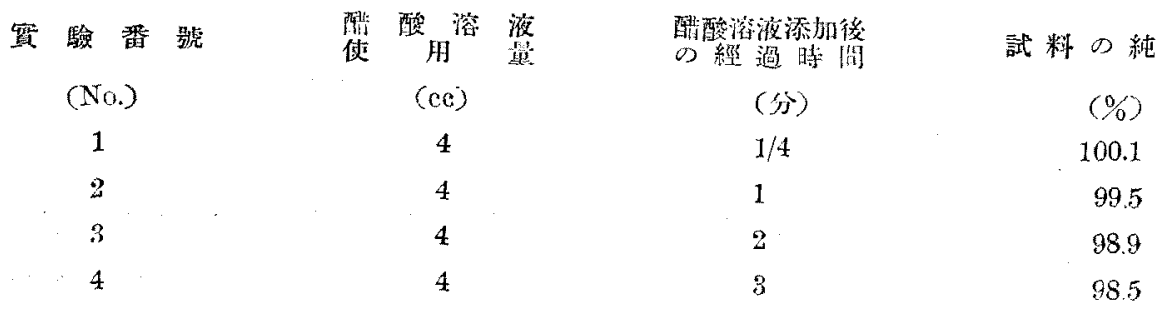


342

$\begin{array}{lrrr} & & & \\ 5 & 4 & 4 & 97.9 \\ 6 & 4 & 5 & 97.7 \\ 7 & 4 & 10 & 97.3 \\ 8 & 4 & 20 & 96.7 \\ 9 & 4 & 30 & 96.3\end{array}$

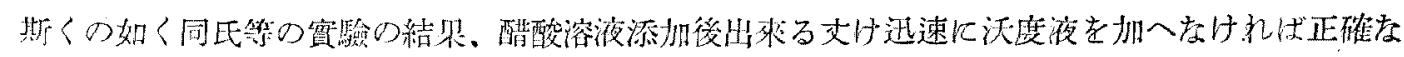

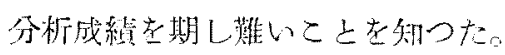

ネスラー氏試藥を以てするフォルムアルデハイド

定量に依万定是分析法の檢敗と操作條件の確立

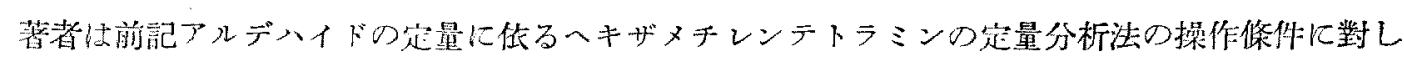

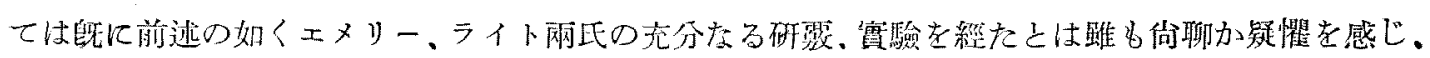

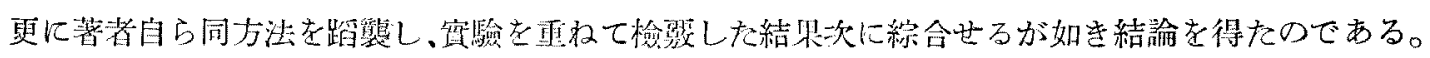

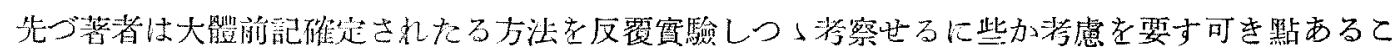

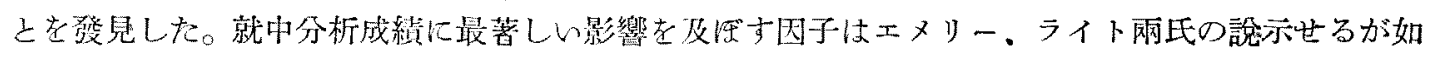

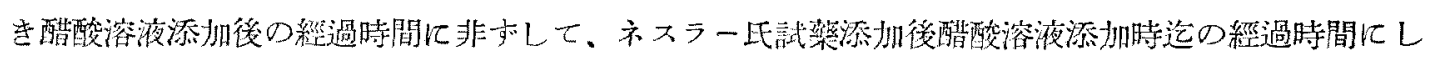
て、フォルムアルデハイドに依るネスラー氏陚葬の還元作用老完結するには相虽時間孝要し且つ此 に對して最適時間のあるととが皿納せられた。

著者は從來の方法に於いては陚料溶液を稀監酸にて分解の後はフォルマリン臭を感知し、常に連 續して些少宛生成されたるつォルムアルデハイドの逃散しつ」西る知つたから此種誤庢を山來る だけ減少させる篇めに出來る大け供武溶液を稀釋して使用し，賽驗中フォルムアルデハイドの揮散

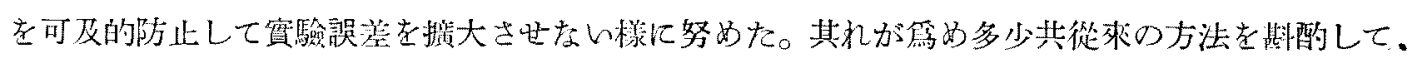

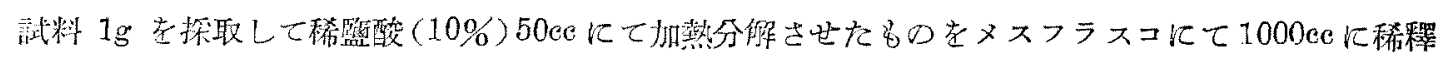
し、此の冈 $25 \mathrm{ee}$ をピペットにて探取し此の $25 \mathrm{ee}$ の分解液 (此の中に試料を 0.025 ，合有し、從 來の方法の探取液に對して殆ど倍量の稀釋度となつてみる）にネスラー氏試藥 $39 \mathrm{ce}($ 前記 A 號試

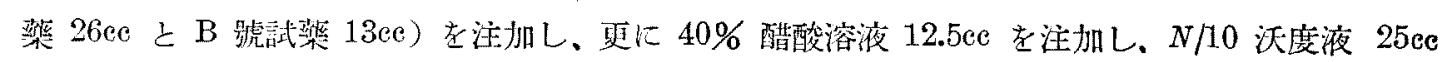
老混和し、最後に過剩の沃度を $N / 20$ チオ硫酸曹埗液にて滴定するととは前法の如く行ひ、次式に 從て純度考算出した。

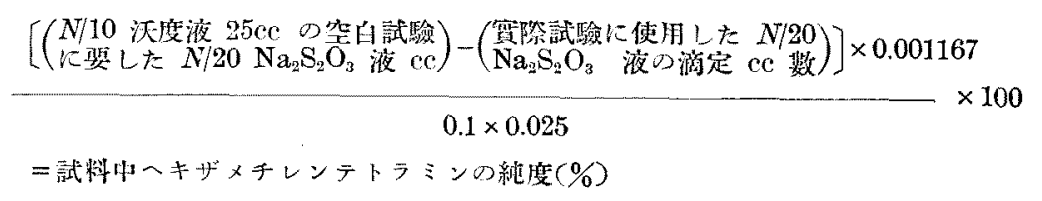

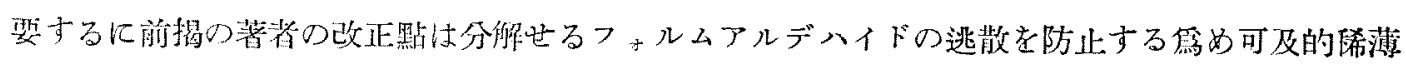

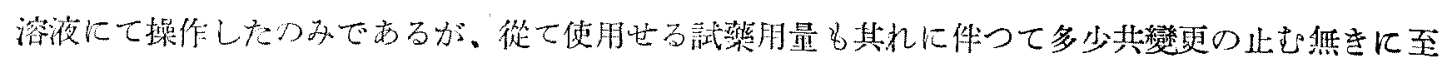


১た。

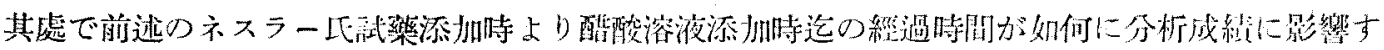

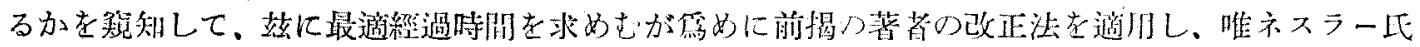

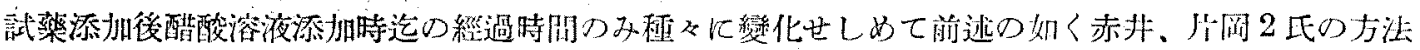

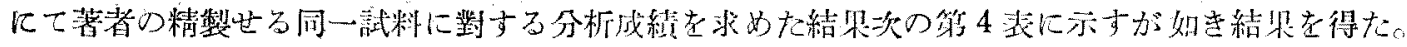

\section{第 4 表}

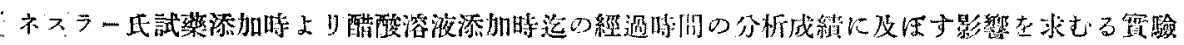

\begin{tabular}{|c|c|c|c|c|}
\hline $\begin{array}{l}\text { 察 羷 番 號 } \\
\text { (No) }\end{array}$ & 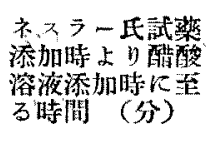 & 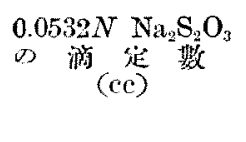 & 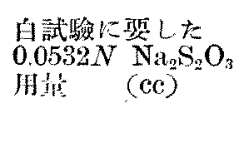 & 純 \\
\hline 1 & 1 & 14.65 & 4939 & 86.27 \\
\hline 2 & 2 & 9.70 & " & 98.56 \\
\hline 3 & 3 & 9.60 & " & 98.81 \\
\hline 4 & 4 & 9.30 & $"$ & 99.56 \\
\hline 5 & 5 & 9.21 & " & 9978 \\
\hline 6 & 6 & 9.10 & "y & 100.06 \\
\hline 7 & 7 & 9.21 & $"$ & 99.78 \\
\hline 8 & 8 & 9.31 & "I & 96.53 \\
\hline
\end{tabular}

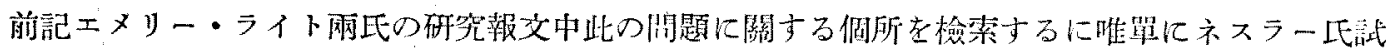

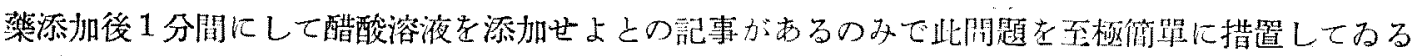

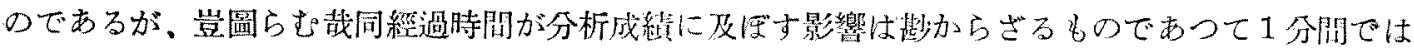
迎ても不足であつて最適時間が 6 分閒でなければなら好とるが前記第 4 表にて明快となつた。

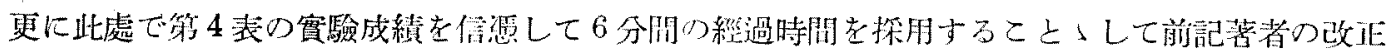

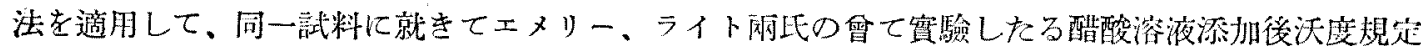

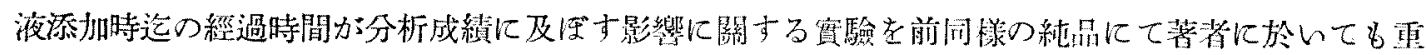
双て繰返し試みた絬果次の笨 5 表の如き絬果老得た。

第 5 表

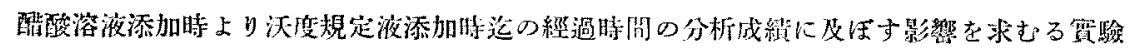

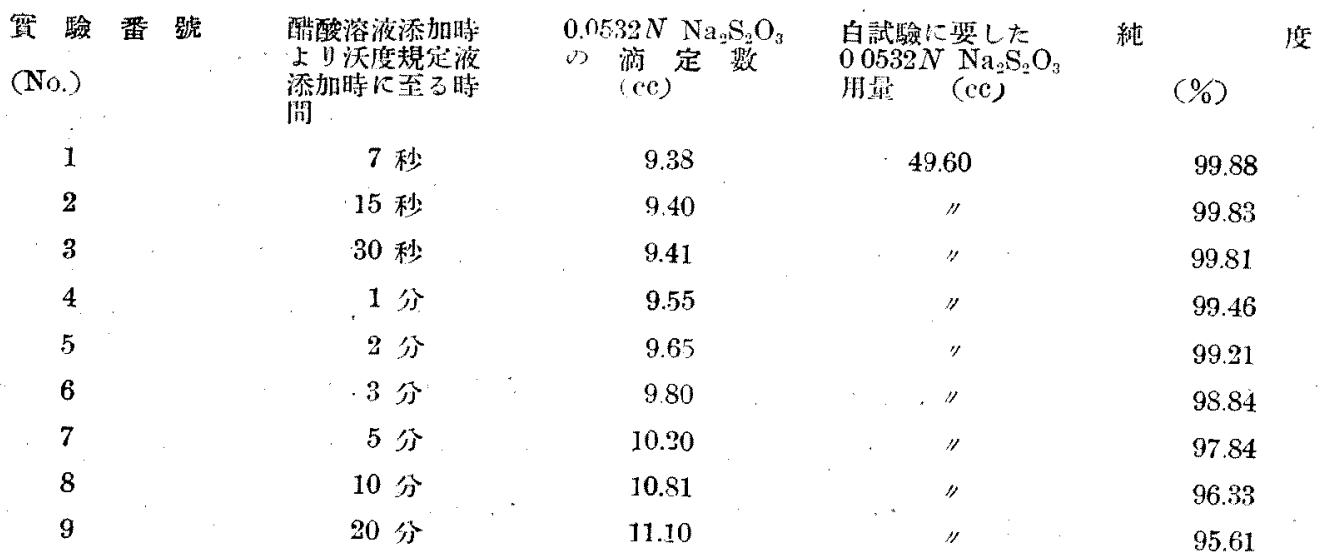




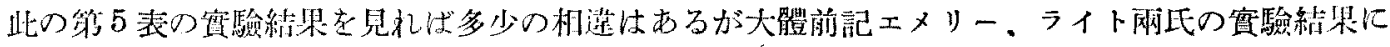
一玫してみて、醋酸溶液源加後出氷る丈け迅速に沃度規定液を加へなければ正しい成績加得られぬ

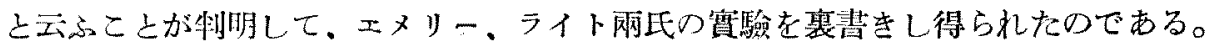

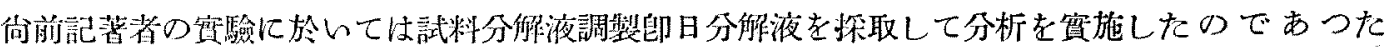
が、場合に依ては分解液調製後日を重权てから此を探取して分析するてとが無いでもないと思はれ る。斯かる場合には前揭の如くフォルムアルデハイドの逃散に低て些か誤荎を誘垤する虞れがない

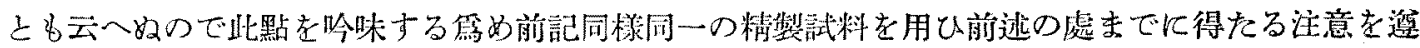

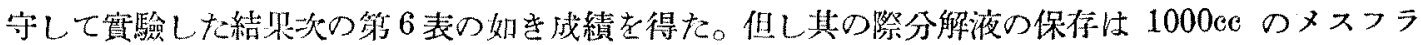

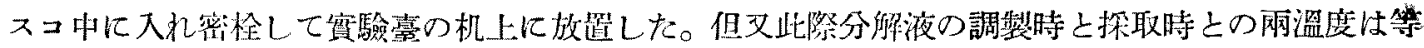
しくなる㥞にした專は云ふ迄もない。

$$
\text { 第 } 6 \text { 韯 }
$$

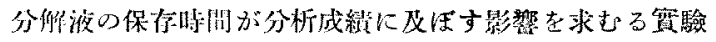

\begin{tabular}{|c|c|c|c|c|}
\hline $\begin{array}{l}\text { 筷 驗 番 號 } \\
\text { (No.) }\end{array}$ & $\begin{array}{l}\text { 分仰倠液の保存期 } \\
\text { 間 }\end{array}$ & 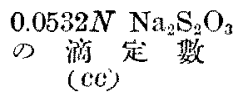 & 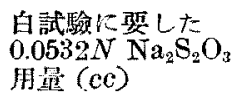 & $\%$ \\
\hline 1 & 即日、的荆 & 9.10 & 49.39 & 100.06 \\
\hline 2 & 1 日後 & 9.26 & " & 99.66 \\
\hline 3 & 2 日後 & 9.29 & 49.40 & 99.61 \\
\hline
\end{tabular}

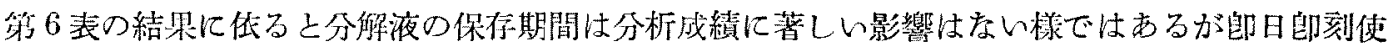

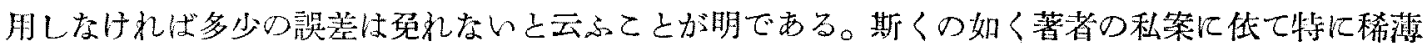
な分解液を使用してすらフォルムアルデハイドの逃散する事赛の存することは否めないから此以上

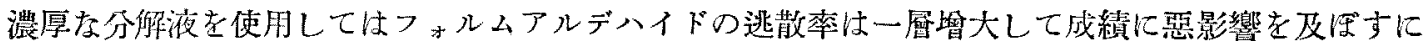
至る事壮碓苗である。

著者の筫驗に依て操作方法老規定されれる前記定星分析 法の紹介、吟味主に市肘商品の分析に對する適用に就て

前述の如く其の操作の細部に瓦つて著者に依て實驗確定されたる條項を聥入して改めて前記定量 分析法主詳說すると炏の如くである。先づ試料 $1 \mathrm{~g}$ を科取して $500 \mathrm{ec}$ の丸底フラスコに入れ、水に 溶解して全容量在 $200 \mathrm{ec}$ と更に $10 \%$ 傿酸 $50 \mathrm{ec}$ (化學用純濃留酸 $26.3 \mathrm{ec}$ に水考加へて $100 \mathrm{cc}$ 上

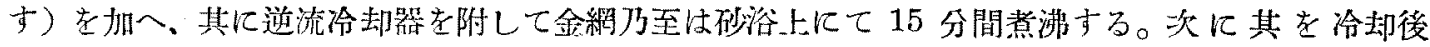
$1000 \mathrm{ee}$ のスフラスコ中に移し、更に逆流椧却器の水洗液も之に侀合し、最後に水を以て $1000 \mathrm{ec}$ に稀釋する。此の分解液 25ee（此中には試料 $0.025 \mathrm{~g}$ を含有する）をピペットにてコニカルビーカ

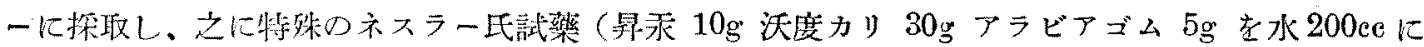

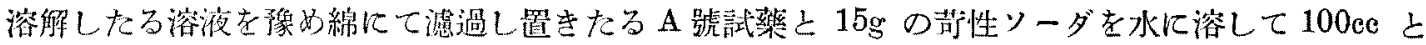




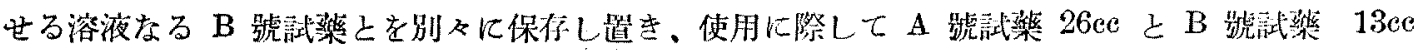

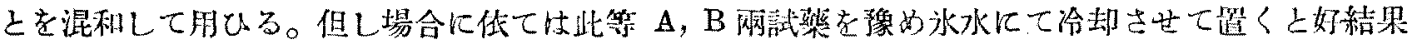
を收むることがある。）39ce をメスシリンダーにて加へ，其のビーカーを挄に呬轉させつ、6分間 經過の後 $40 \%$ 水醋酸溶液 $12.5 \mathrm{ec}$ をメスシリンスダーにて扣へて速に混和しつ」 7 秒以冈に $N / 10$ 沃度液 25ee を猚如ピペットにて小さなビーカーに探取し遗をたるものを一氣呵成に注加し、ビー

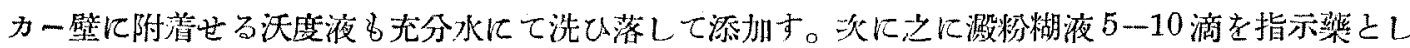
て加へ $N / 20 \quad \mathrm{Na}_{2} \mathrm{~S}_{2} \mathrm{O}_{3}$ 液にて湤定し、次式に從てへキザメチレンテトラミンの純度を算出した。但 し别に同 $N / 10$ 沃度液 $25 \mathrm{ec}$ 老科取して前同様に $N / 20 \quad \mathrm{Na}_{2} \mathrm{~S}_{2} \mathrm{O}_{3}$ 液にて滴定して空白試驗考施行す ることが必要である。

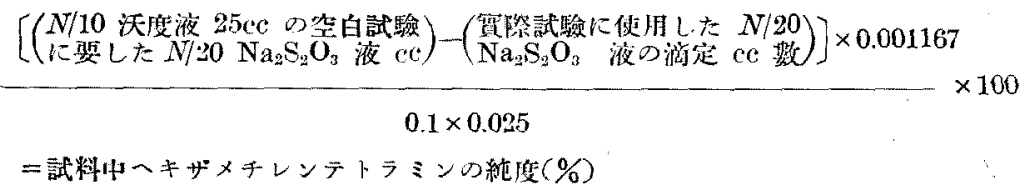

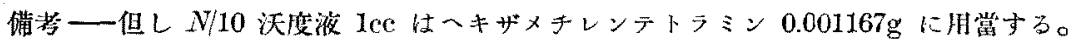

次に斯く著者に依て細目に互つて操作方法を確立されたる前記䇥量分析法の正確度を吟味せ九が 䉆めに前述の赤井，片岡网同の方法にて藷者自身にて精製せる極めて純粹と思考せられるへキザメ チレンテトラミンの標蕉試料に就著者の催芫せる同定量分析法を適用せるに次の第7 表の如き結 果索得た。

第 7 装

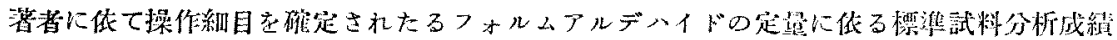

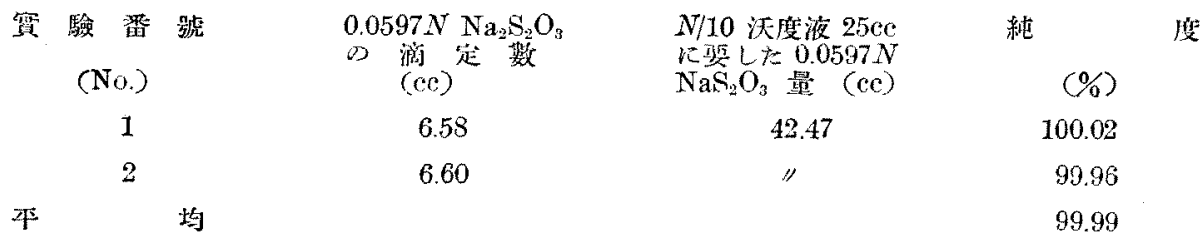

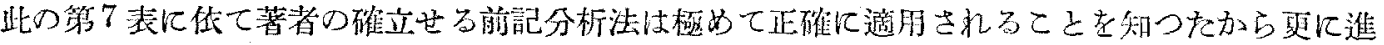
んで此の方法を其ま」適用して 2;3の市販硫化促進敌用へキザメチレンテトラミン分析した結果 次の第 8 表の如き成績を得た。

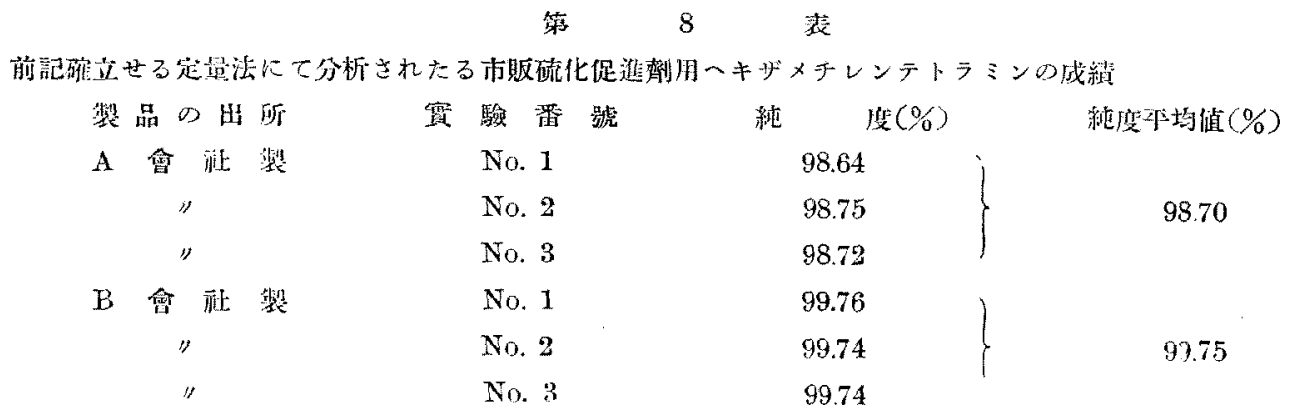




\section{摘 装}

前就喃告の全文を一括すると次の如くである。

（1）へキザメチレンテトラミンの鑑識上定量分析とに就いて從來の方法を調查. 檢覀して其の内 最避上思若さ机る力法在平易に紹介した。

（2）へキザメチレンテトラミンの純度测定に際しては、此を分獬して、生成されたるアンモニア

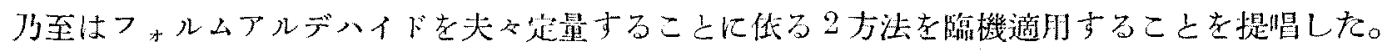

（3）フォルムアルデ入イドを管量することに依る方法中、分解せしめたるフォルムアルデハイド

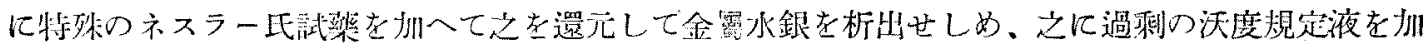
へて沃化水銀を化成せしめ。過剩の沃度を千才硫酸ソーダ規定液にて滴定して定量する方法を推獎 して、之を反㠅惯㬭して考察吟味した。

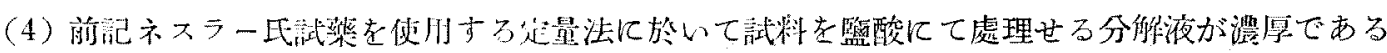

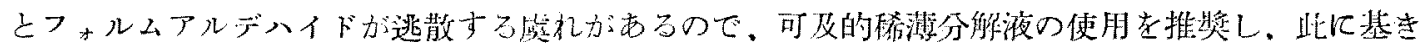
て著省自身の方洁を述べた。

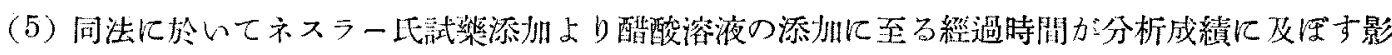

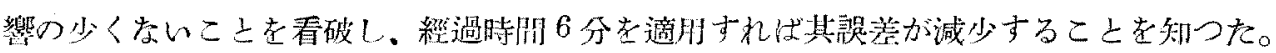

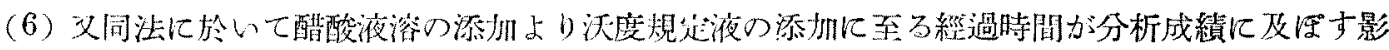

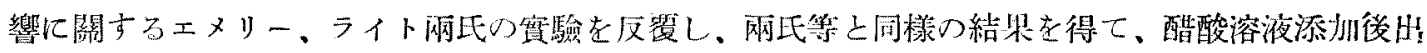

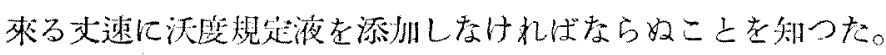

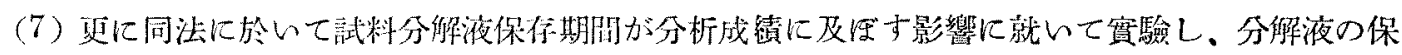
保が長時闑に互る上些か誤差を惹起し易いから、分解液は調製賞時。速刻使用するに若くはないこ とを確㣌た。

附記、本研究の實施汇際して終始御愁篤なる御垂教を赐りたる電氣試驗所第五部長、工學博士小

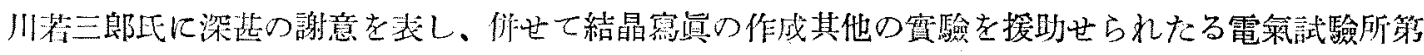

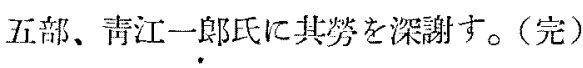

